\title{
PORTABLE NEAR INFRARED SPECTROMETER DENGAN SENSOR AS7263 UNTUK PENDUGAAN SIFAT KIMIA JERUK SIAM (CITRUS NOBILIS) SECARA NON-DESTRUKTIF
}

\author{
Portable Near Infrared Spectrometer with Sensor AS7263 \\ for Non-Destructive Estimation of Chemical Properties of \\ Siamese Citrus (Citrus nobilis)
}

\author{
Susanto B. Sulistyo*, Arief Sudarmaji, Siswantoro, Agus Margiwiyatno, Masrukhi, \\ Asna Mustofa, Rifah Ediati, Riana Listanti, Hety Handayani Hidayat \\ Program Studi Teknik Pertanian - Fakultas Pertanian - Universitas Jenderal Soedirman \\ Jl. Dr. Soeparno - Karangwangkal - Purwokerto 53123 \\ *Penulis Korespondensi, email: susanto.sulistyo@unsoed.ac.id
}

\begin{abstract}
ABSTRAK
Evaluasi mutu buah jeruk secara umum masih dilakukan secara destruktif. Penelitian ini bertujuan untuk memprediksi kandungan kimia buah jeruk siam secara non-destruktif menggunakan Near Infrared Spectrometer portable dengan sensor AS7263 dan aplikasi Neural Network Ensemble (NNE) dengan genetic algorithm (GA) untuk optimasi. Keluaran dari enam channel NIRS portable digunakan sebagai input NNE. NNE yang dikembangkan terdiri atas empat buah Backpropagation Neural Network (BPNN) dengan dua buah lapisan tersembunyi dan kombinasi transfer function yang berbeda-beda. Keluaran dari keempat $B P N N$ ini digabung untuk menghasilkan keluaran NNE yang baru dan dioptimasi menggunakan GA. Karakteristik kimia buah jeruk yang diestimasi adalah total padatan terlarut (TPT) dan vitamin C. Hasil penelitian menunjukkan bahwa akurasi estimasi NNE lebih tinggi dibandingkan akurasi sebuah BPNN tunggal. Estimasi kadar TPT buah jeruk siam menggunakan NNE berbasis GA tergolong sangat akurat dengan nilai Mean Absolut Percentage Error (MAPE) 8,04\%. Adapun estimasi kadar vitamin C menggunakan NNE berbasis GA tergolong akurat dengan MAPE sebesar $11,02 \%$. Namun demikian, hasil penelitian ini masih perlu dilanjutkan untuk mengetahui performansi alat yang dikembangkan untuk memprediksi mutu internal jeruk varietas lain yang berbeda karakteristik fisikokimianya.
\end{abstract}

Kata kunci: Backpropagation Neural Network; Inframerah; Jaringan Syaraf Tiruan; Total Padatan Terlarut; Vitamin C

\begin{abstract}
In general, the evaluation of the quality of citrus is still carried out destructively. This study aimed to predict the chemical characteristics, i.e. Total Soluble Solids (TSS) and vitamin C, of Siamese citrus nondestructively using a portable Near Infrared Spectrometer (NIRS) with the AS7263 sensor and the application of the neural network ensemble (NNE) with a Genetic Algorithm (GA) for optimization. The outputs of the six portable NIRS channels were used as predictors of the NNE. The developed NNE consisted of four backpropagation neural networks (BPNN) with two hidden layers and different combinations of transfer functions. The outputs of the four BPNNs were combined to produce new NNE outputs and were then optimized using GA. The results showed that the NNE estimation accuracy was higher than that of a single BPNN. The estimation of TSS content of Siamese citrus using GA-optimized NNE was classified as very accurate with a Mean Absolute Percentage Error (MAPE) of 8.04\%. The estimation of vitamin C using GA-optimized NNE was classified as accurate with a MAPE of $10.01 \%$.
\end{abstract}


Jurnal Teknologi Pertanian Vol. 22 No. 2 [Agustus 2021] 81-88

Portable Near Infrared Spectrometer dengan Sensor AS7263 untuk Pendugaan Sifat Kimia Jeruk Siam

[Sulistyo dkk]

However, the results of this study still need to be continued to determine the performance of the instrument developed to predict the internal quality of other citrus varieties with different physicochemical characteristics.

Keywords : Artificial Neural Network; Backpropagation Neural Network; Infrared; Total Soluble Solids; Vitamin C

\section{PENDAHULUAN}

Jeruk merupakan salah satu buah yang melimpah, diprediksikan produksinya mencapai 115 juta ton per tahun di seluruh dunia (Olabinjo et al., 2017). Jeruk umumnya merupakan sumber vitamin $C$ yang berguna untuk kesehatan manusia. Jeruk juga dibutuhkan sebagai sumber bioaktiva termasuk anti oksidan seperti asam askorbat, flavanoid dan fenolik yang dibutuhkan oleh tubuh manusia (Ghasemi et al., 2009).

Evaluasi mutu produk pertanian sangat penting peranannya untuk menjamin bahwa produk tersebut sesuai standar yang telah ditetapkan. Selain untuk sortasi dan grading, informasi tentang karakteristik fisik dan kimia produk pertanian juga perlu diketahui karena berkaitan dengan pemilihan maupun desain alat mesin untuk pengolahan, pengemasan, dan proses produksi lainnya. Beberapa karakteristik fisik dan kimia buah jeruk yang menjadi parameter dalam proses sortasi dan grading di anataranya adalah ukuran, warna, tekstur, kekerasan dan keasaman.

Selain dalam proses pasca panen, pengetahuan tentang karakteristik buah jeruk juga diperlukan pada saat masa panen untuk penentuan kematangan buah. Pada umumnya proses evaluasi mutu jeruk, seperti pengukuran kadar air, total padatan terlarut, keasaman $(\mathrm{pH})$, kadar gula, dan vitamin $\mathrm{C}$, dilakukan secara destruktif dengan cara merusak produk. Walaupun hasilnya akurat, namun metode destruktif membutuhkan waktu yang relatif lama dan keterampilan khusus untuk analisis laboratorium.

Near infrared (NIR) spectrometer sudah dimanfaatkan pada beberapa penelitian untuk evaluasi mutu produk pertanian secara nondestruktif. Shao et al. (2009) mengklasifikasikan jeruk berdasarkan kondisi pertumbuhan dan area geografisnya serta memprediksi kandungan gula dalam buah jeruk menggunakan NIR spectrometer. Khodabakhshian et al. (2017) meneliti penggunaan spektroskopi cahaya tampak dan NIR untuk penentuan kematangan dan parameter mutu buah delima. Soltanikazemi et al. (2017) juga mengaplikasikan visible/near infrared spectroscopy dengan algoritma genetik untuk memprediksi mutu internal buah black mulberry. Alhamdan dan Atia (2018) menggunakan NIR spectrometer untuk memprediksi kualitas buah kurma pada berbagai tingkat kematangan.

Pada umumnya penelitian-penelitian untuk menduga kandungan internal produk pertanian yang telah dilakukan sebelumnya menggunakan perangkat NIR spectrometer skala laboratorium. Perangkat ini mempunyai beberapa kelemahan yaitu harga yang sangat mahal, memerlukan keahlian khusus untuk mengoperasikannya, dan bentuknya cukup besar sehingga tidak praktis untuk operasional di luar laboratorium. Untuk menjawab tantangan tersebut, penelitian ini mengaplikasikan portable NIR spectrometer dengan sensor AS7263 yang harganya lebih murah, mudah dalam mengoperasikannya dan mudah diaplikasikan di lapangan. Sensor NIR AS7263 terdiri atas enam filter optik yang mempunyai respons terhadap spektrum cahaya NIR dengan panjang gelombang antara 600-870 nm (Ams, 2021).

Pada penelitiannya, Qomariah et al. (2013) menemukan bahwa jeruk siam mempunyai karakter sifat fisik warna kulit yang tidak berkorelasi linier dengan sifat kimianya, seperti tingkat kemanisan dan keasamannya, yang dalam hal ini direpresentasikan dengan nilai TPT. Oleh karena itu, backpropagation neural network lebih tepat digunakan untuk mengestimasi kandungan kimia jeruk yang bersifat nonlinier terhadap parameter fisiknya dibandingkan dengan metode analitik atau statistik biasa seperti regresi linier sederhana atau regresi linier berganda dan yang lainnya.

Backpropagation neural network (BPNN) sudah banyak diaplikasikan dalam berbagai 
bidang, termasuk pertanian, baik untuk tujuan klasifikasi maupun regresi (estimasi) (Dimililer dan Kiani, 2017; Herulambang, 2016; Lesnussa et al., 2018; Rao et al., 2019). Namun demikian, salah satu kekurangan penggunaan $B P N N$ adalah nilai output yang selalu berubah pada setiap kali training dikarenakan nilai bobot awal pada setiap neuron berbeda-beda. Selain itu, perbedaan struktur BPNN juga dapat mempengaruhi output BPNN sehingga sulit dan memerlukan banyak waktu untuk menentukan satu arsitektur BPNN tunggal yang tepat untuk menyelesaikan sebuah persoalan (Ruta dan Gabrys, 2000). Untuk mengatasi permasalahan tersebut, dikembangkan algoritma neural network ensemble (NNE) dengan cara menggabungkan beberapa BPNN dengan arsitektur yang berbeda namun menggunakan input yang sama (Rothe et al., 2019). Beberapa penelitian juga menunjukkan bahwa penggabungan beberapa neural network terbukti dapat meningkatkan akurasi klasifikasi atau estimasi dibandingkan dengan menggunakan satu neural network tunggal (Zhou et al., 2002; Liang et al., 2014; Sulistyo et al., 2018). Penelitian ini bertujuan untuk mengestimasi total padatan terlarut (TPT) dan vitamin C buah jeruk Siam secara non-destruktif menggunakan portable NIR spectrometer berbasis sensor AS7263 dan neural networks ensemble dengan genetic algorithm untuk optimasi.

\section{METODE}

Bahan yang digunakan dalam penelitian ini adalah buah jeruk siam, serta larutan iodin dan larutan amilum untuk pengukuran kadar vitamin C. Jeruk siam (Citrus nobilis) yang digunakan dalam penelitian ini sebanyak 300 buah yang diambil secara acak di kebun yang sama, yaitu dari perkebunan Agrowisata Botani Garden (Bogar) di Desa Karangcengis, Kecamatan Bukateja, kabupaten Purbalingga. Alat-alat yang digunakan adalah portable NIR spectrometer dengan sensor AS7263, refraktometer, dan alat titrasi vitamin C.

Seperti terlihat pada Gambar 1 dan Gambar 2, alat portable NIR spectrometer yang digunakan terdiri atas beberapa komponen, yaitu lampu LED, NIR receiver, penguat sinyal, dan konektor ke PC/laptop. Sensor AS7263 mempunyai enam channel NIR, yaitu channel R,
$\mathrm{S}, \mathrm{T}, \mathrm{U}, \mathrm{V}$, dan $\mathrm{W}$ dengan respons spektral terhadap cahaya dengan panjang gelombang masing-masing adalah $610 \mathrm{~nm}$, $680 \mathrm{~nm}, 730 \mathrm{~nm}, 760 \mathrm{~nm}, 810 \mathrm{~nm}$ dan $860 \mathrm{~nm}$. Gambar 3 memperlihatkan skema cara kerja alat yang dikembangkan yaitu dengan memanfaatkan pantulan cahaya LED yang mengenai obyek buah jeruk. Pantulan cahaya tersebut ditangkap oleh sensor infrared dan keluaran nilainya dibaca oleh komputer dengan menggunakan bahasa pemrograman Arduino. Adapun cara peletakan obyek buah jeruk pada sensor terlihat seperti pada Gambar 4.

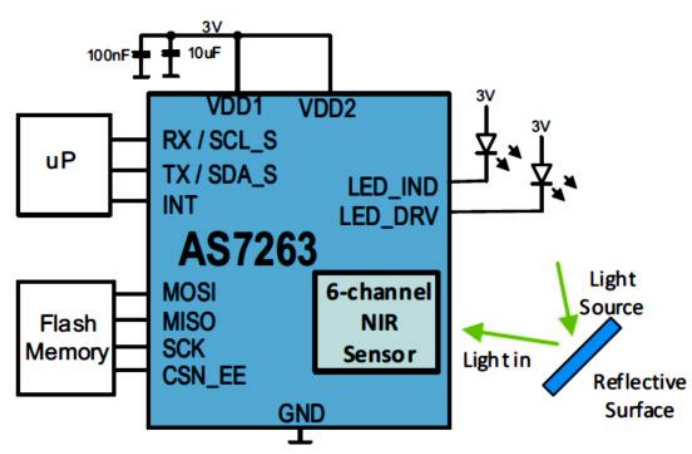

Gambar 1. Diagram blok sensor AS7263 (Ams, 2021)

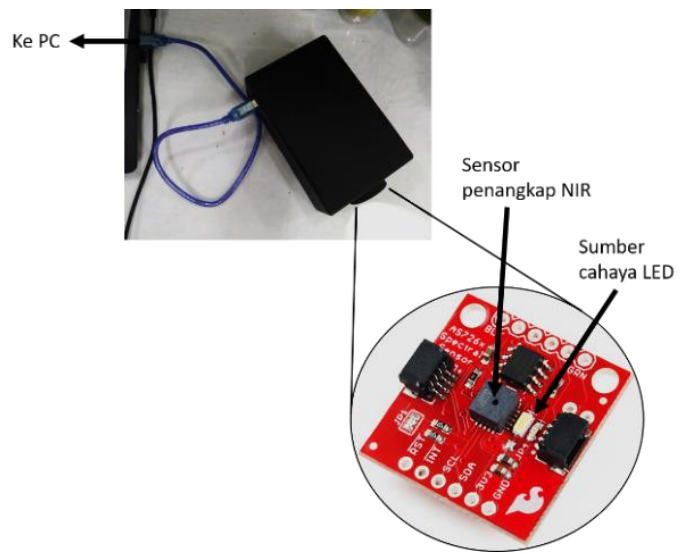

Gambar 2. Alat portable NIR spectrometer dengan sensor AS7263 
Jurnal Teknologi Pertanian Vol. 22 No. 2 [Agustus 2021] 81-88

Portable Near Infrared Spectrometer dengan Sensor AS7263 untuk Pendugaan Sifat Kimia Jeruk Siam [Sulistyo dkk]

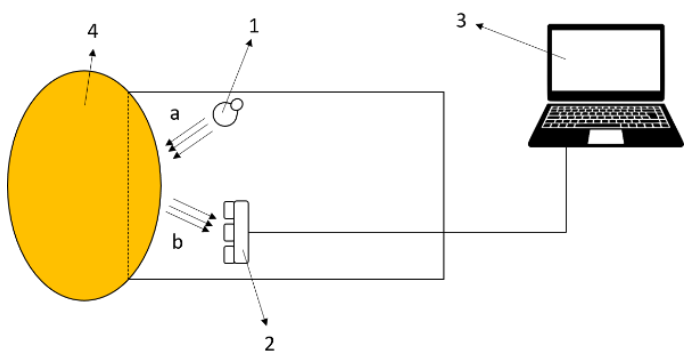

Keterangan gambar:

1. LED; 2. Sensor NIR; 3. Komputer; 4 . Sampel buah jeruk. a. Cahaya LED ke obyek; b. Pantulan cahaya dari buah jeruk ke sensor infrared.

Gambar 3. Skema interaksi sumber cahaya, obyek, dan sensor NIR

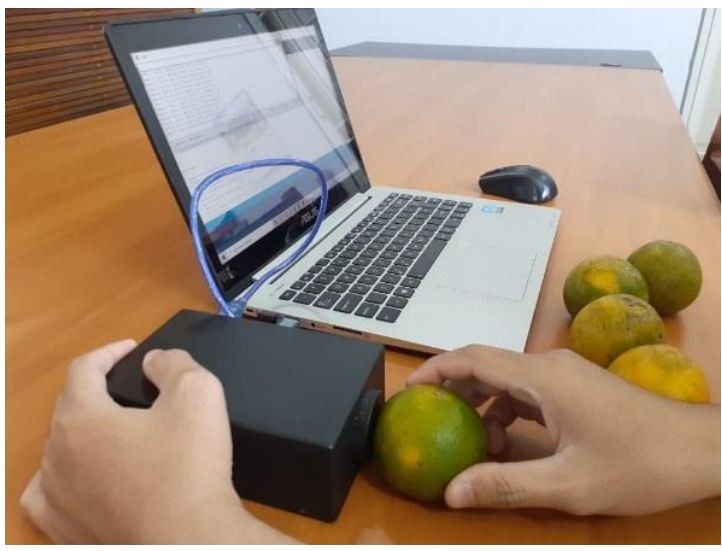

Gambar 4. Peletakan obyek jeruk pada sensor NIR

\section{Tahapan Penelitian}

Tahapan penelitian ini dilakukan dengan mula-mula kulit jeruk dibersihkan dari kotoran yang menempel. Selanjutnya, sampel jeruk diletakkan pada sensor NIR seperti terlihat pada Gambar 4. Ketika alat dinyalakan, lampu LED menyala dan mengenai sampel buah jeruk. Sebagian cahaya yang mengenai buah jeruk dipantulkan dan spektrum NIR pada kisaran panjang gelombang 600-870 nm ditangkap oleh sensor. Pantulan (reflektansi) NIR inilah yang terbaca pada program Arduino 1.8.12 yang dikembangkan sebagai nilai keluaran (output) sensor. Data ini kemudian disimpan sebagai database dalam MS Excel.

Langkah berikutnya adalah analisis kandungan kimia buah jeruk secara destruktif untuk mendapatkan nilai aktualnya. Cara yang dilakukan adalah dengan mengekstrak sari buah jeruk dan kemudian diukur kandungan TPT menggunakan refraktometer dan kandungan vitamin $C$ menggunakan metode titrasi (AOAC, 2005).

Data ouput sensor yang terdiri atas enam channel dan kandungan kimia aktual yang terdiri atas dua parameter selanjutnya disusun untuk membuat sebuah dataset untuk program jaringan syaraf tiruan yang dikembangkan. Dari 300 sampel buah jeruk yang diperoleh, sebanyak 210 sampel (70\%) digunakan untuk training dan sisanya sejumlah 90 buah (30\%) untuk testing. Neural network yang diaplikasikan di penelitian ini adalah backpropagation neural network $(B P N N)$ dengan dua lapisan tersembunyi (hidden layer), seperti terlihat pada Gambar 5. Neural network pada penelitian ini dikembangkan dengan menggunakan bahasa pemrograman Matlab R2009b.

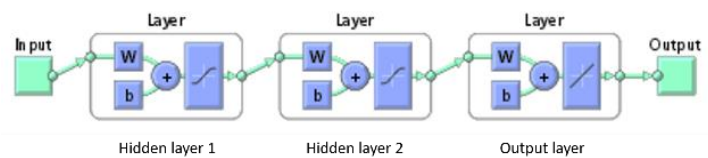

Gambar 5. Arsitektur BPNN dengan 2 hidden layer

Pada penelitian ini juga dikombinasikan transfer function yang berbeda-beda pada dua lapisan tersembunyi. Transfer function yang digunakan ada dua macam, yaitu logistic sigmoid (logsig) dan hyperbolic tangent sigmoid (tansig). Jadi ada empat BPNN tunggal dengan kombinasi transfer function pada dua hidden layer, yaitu sebagai berikut:

1) BPNN \#1 : logsig - logsig

2) BPNN \#2 : logsig - tansig

3) BPNN \#3 : tansig - logsig

4) BPNN \#4 : tansig - tansig

Adapun fungsi log-sig dan tan-sig dapat diekspresikan dengan formula matematis yang ditunjukkan pada Persamaan (1) dan (2).

Log-sig: $f(x)=\frac{1}{1+e^{-x}}$

Tan-sig: $f(x)=\frac{e^{x}-e^{-x}}{e^{x}+e^{-x}}$

Neural networks ensemble (NNE) yang dikembangkan dalam penelitian ini dilakukan dengan cara menggabungkan empat BPNN tunggal yang sudah disebutkan sebelumnya. Penggabungan 
empat BPNN ini dilakukan dengan dua cara, yaitu simple average (sa-NNE) dan weighted average (wa-NNE). Metode simple average dilakukan dengan menghitung rata-rata keluaran empat BPNN tunggal untuk menghasilkan satu keluaran baru sehingga koefisien untuk masing-masing keluaran $B P N N$ sama. Pada metode weighted average masing-masing keluaran BPNN memiliki koefisien yang berbeda untuk untuk menghasilkan satu keluaran baru seperti yang ditunjukkan pada Persamaan (3) dan (4) (Sulistyo et al., 2018).

$O_{N}=\sum_{i=1}^{K} O_{i} * w_{i}$

dengan

$\sum_{i=1}^{K} w_{i}=1$

dimana:

$O_{N}=$ keluaran baru dari $N N E$

$O_{i}=$ keluaran $B P N N$ ke- $i$

$w_{i}=$ koefisien keluaran $B P N N$ ke- $i$

$K=$ jumlah $B P N N$

Optimasi pembobotan pada metode weighted average dilakukan dengan menggunakan algoritma genetic algorithm (GA). Arsitektur wa-NNE dapat dilihat pada Gambar 6. Untuk mengurangi nilai variance akibat perbedaan nilai bobot awal, proses training neural network diulang sebanyak sepuluh kali dan dirata-ratakan. GA yang diaplikasikan untuk optimasi pembobotan menggunakan parameter sebagai berikut:

-Populasi awal $=1200$

-Panjang string $=10$

-Laju mutasi $=0,15$

Mean absolute percentage error (MAPE) digunakan untuk menentukan tingkat keberhasilan estimasi. Nilai MAPE dapat dihitung dengan menggunakan formula pada Persamaan (5) (Sulistyo et al., 2018).

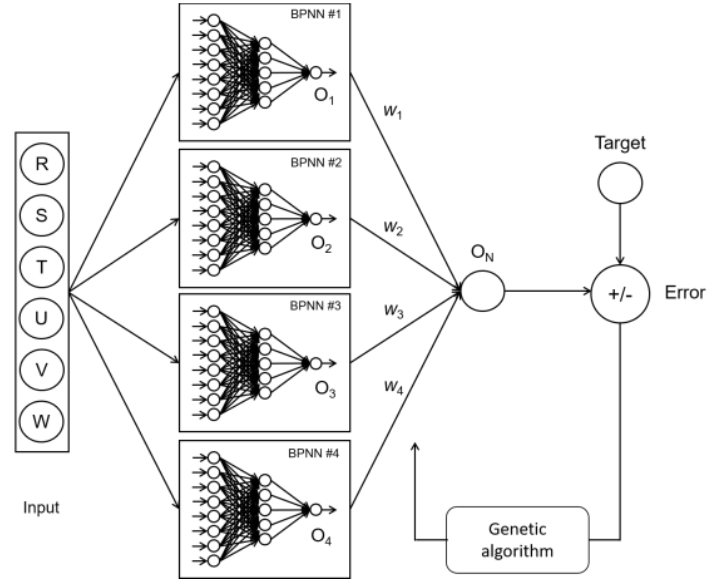

Gambar 6. Arsitektur NNE dengan optimasi menggunakan GA (Sulistyo et al., 2018)

$M A P E=\frac{1}{P} \sum_{j=1}^{P} \frac{a b s\left(T_{j}-O_{j}\right)}{o_{j}} \times 100 \%$

dimana

$P=$ jumlah sampel

$T=$ nilai aktual $/$ target

$O=$ nilai estimasi (keluaran neural network)

MAPE menunjukkan seberapa besar penyimpangan nilai estimasi terhadap nilai aktualnya. Algoritma BPNN yang diterapkan dalam penelitian ini adalah untuk tujuan estimasi, bukan untuk klasifikasi, sehingga MAPE lebih tepat digunakan untuk menggambarkan tingkat keberhasilan prediksi sifat kimia jeruk siam berdasarkan reflektansi cahaya NIR. Interpretasi tingkat akurasi sebuah model prediksi berdasarkan nilai MAPE dapat dilihat pada Tabel 1 (Chen, et al., 2008; Putro, et al., 2018).

Tabel 1. Interpretasi nilai MAPE terhadap akurasi model prediksi

\begin{tabular}{ll}
\hline MAPE & Akurasi \\
\hline$<10 \%$ & Sangat Akurat \\
$10 \%-20 \%$ & Akurat \\
$20 \%-50 \%$ & Cukup akurat/Wajar \\
$>50 \%$ & Tidak akurat \\
\hline
\end{tabular}


Jurnal Teknologi Pertanian Vol. 22 No. 2 [Agustus 2021] 81-88

Portable Near Infrared Spectrometer dengan Sensor AS7263 untuk Pendugaan Sifat Kimia Jeruk Siam

[Sulistyo dkk]

\section{HASIL DAN PEMBAHASAN}

\section{Estimasi Total Padatan Terlarut}

Pada 300 sampel buah jeruk siam (Citrus nobilis) yang diperoleh, rata-rata total padatan terlarutnya adalah 10,0 Brix dengan kisaran antara 7,2-12,2 ${ }^{\circ}$ Brix. Hasil training dan testing dari keempat BPNN tunggal yang masingmasing mempunyai dua hidden layer menunjukkan nilai MAPE yang relatif kecil yaitu sekitar $6 \%$ dan $8 \%$, seperti terlihat pada Tabel 2.

Tabel 2. Nilai MAPE BPNN tunggal pada estimasi kandungan TPT

\begin{tabular}{ccc}
\hline \multirow{2}{*}{ BPNN } & \multicolumn{2}{c}{ MAPE } \\
\cline { 2 - 3 } & Training & Testing \\
\hline BPNN \#1 & $6,22 \%$ & $8,36 \%$ \\
BPNN \#2 & $6,20 \%$ & $8,34 \%$ \\
BPNN \#3 & $6,27 \%$ & $8,40 \%$ \\
BPNN \#4 & $6,04 \%$ & $8,52 \%$ \\
\hline
\end{tabular}

Pada Tabel 2 terlihat bahwa tingkat akurasi $B P N N$ tunggal masih tergolong sangat akurat yang ditunjukkan dengan nilai $M A P E$ yang bernilai kurang dari $10 \%$. Namun demikian, hasil penelitian juga menunjukkan bahwa NNE yang dikembangkan dapat meningkatkan akurasi estimasi kandungan TPT buah jeruk yang ditandai dengan menurunnya nilai MAPE dibandingkan keempat BPNN tunggal. Hal ini juga sejalan dengan penelitian yang dilakukan oleh Mi et al. (2016) yang membuktikan bahwa kombinasi beberapa neural network dapat meningkatkan performansi model estimasi atau regresi dibandingkan neural network tunggal. Nilai $M A P E$ dari sa-NNE dan wa-NNE untuk estimasi kandungan TPT dapat dilihat pada Tabel 3.

Tabel 3. Nilai MAPE NNE pada estimasi kandungan TPT

\begin{tabular}{ccc}
\hline \multirow{2}{*}{ NNE } & \multicolumn{2}{c}{ MAPE } \\
\cline { 2 - 3 } & Training & Testing \\
\hline sa-NNE & $5,80 \%$ & $8,07 \%$ \\
wa-NNE & $5,72 \%$ & $8,04 \%$ \\
\hline
\end{tabular}

Pada Tabel 3 terlihat bahwa wa-NNE mempunyai nilai error yang lebih kecil dibandingkan sa-NNE. Hal ini menunjukkan bahwa kontribusi setiap BPNN tunggal untuk menghasilkan nilai keluaran baru yang mendekati nilai target berbeda-beda yang diperlihatkan dengan nilai koefisien yang berbeda. Hasil penelitian, GA yang diaplikasikan terbukti dapat menghasilkan koefisien yang optimal untuk masingmasing $B P N N$, yaitu 0,$22 ; 0,23 ; 0,23$; dan 0,32 sehingga nilai estimasi TPT $\left(O_{T P T}\right)$ dapat menggunakan Persamaan (6) dan (7).

$\mathbf{0}_{\mathrm{TPT}}=\mathbf{0}^{\mathrm{T}} \cdot \mathbf{w}$

$O_{T P T}=\left[\begin{array}{l}O_{1} \\ O_{2} \\ O_{3} \\ O_{4}\end{array}\right]^{T} \times\left[\begin{array}{l}0,22 \\ 0,23 \\ 0,23 \\ 0,32\end{array}\right]$

Pada persamaan (7) dapat dikatakan bahwa model BPNN \#1, BPNN \#2 dan $B P N N$ \#3 mempunyai kontribusi yang relatif sama. Hal ini terlihat dari nilai bobot (w) pada kombinasi NNE. BPNN \#4 mempunyai kontribusi yang paling besar dalam NNE tersebut untuk memprediksi TPT buah jeruk, yang ditunjukkan dengan nilai bobot yang paling besar $(w=0,32)$.

\section{Estimasi Kandungan Vitamin C}

Sampel buah jeruk yang digunakan pada penelitian ini mempunyai kandungan vitamin C rata-rata sebesar $57,4 \mathrm{mg} / 100 \mathrm{~g}$ dengan kisaran antara 35,2-81,8 mg/100 g. Data Departemen Kesehatan Republik Indonesia (1995) menyebutkan bahwa komposisi vitamin C rata-rata per $100 \mathrm{~g}$ sari buah jeruk siam adalah sekitar $49 \mathrm{mg}$.

Hasil penelitian menunjukkan bahwa tingkat akurasi estimasi vitamin $\mathrm{C}$ menggunakan BPNN tunggal tergolong akurat yang ditunjukkan dengan nilai MAPE antara $10-20 \%$, seperti terlihat pada Tabel 4.

Tabel 4. Nilai MAPE BPNN tunggal pada estimasi vitamin C

\begin{tabular}{ccc}
\hline \multirow{2}{*}{ BPNN } & \multicolumn{2}{c}{ MAPE } \\
\cline { 2 - 3 } & Training & Testing \\
\hline BPNN \#1 & $10,66 \%$ & $11,03 \%$ \\
BPNN \#2 & $10,43 \%$ & $10,70 \%$ \\
BPNN \#3 & $10,69 \%$ & $11,56 \%$ \\
BPNN\#4 & $11,57 \%$ & $11,59 \%$ \\
\hline
\end{tabular}

Seperti halnya pada prediksi kandungan TPT, NNE yang dikembangkan 
juga dapat menurunkan MAPE estimasi vitamin C. Hal ini semakin menguatkan pembuktian bahwa kombinasi beberapa neural network dapat meningkatkan akurasi model estimasi dibandingkan dengan satu neural network tunggal. Optimasi berbasis GA pada pembobotan $B P N N$ juga mampu menghasilkan estimasi yang lebih baik dibandingkan dengan pembobotan rata-rata, seperti terlihat pada Tabel 5 .

Tabel 5. Nilai MAPE NNE pada estimasi vitamin C

\begin{tabular}{ccc}
\hline \multirow{2}{*}{ NNE } & \multicolumn{2}{c}{ MAPE } \\
\cline { 2 - 3 } & Training & Testing \\
\hline sa-NNE & $9,72 \%$ & $10,81 \%$ \\
wa-NNE & $9,60 \%$ & $10,01 \%$ \\
\hline
\end{tabular}

Dari sepuluh kali ulangan proses training neural network, koefisien yang optimal untuk masing-masing BPNN pada pendugaan kadar vitamin $C$, yaitu 0,$21 ; 0,32 ; 0,21 ; 0,26$ sehingga nilai estimasi vitamin $\mathrm{C}\left(\mathrm{O}_{\text {vitc }}\right)$ dapat dituliskan pada Persamaan (8) dan (9).

$\mathbf{O}_{\text {vitC }}=\mathbf{0}^{\mathrm{T}} \cdot \mathbf{w}$

$O_{\text {vitC }}=\left[\begin{array}{c}O_{1} \\ O_{2} \\ O_{3} \\ O_{4}\end{array}\right]^{T} \times\left[\begin{array}{l}0,21 \\ 0,32 \\ 0,21 \\ 0,26\end{array}\right]$

Pada persamaan (9) terlihat bahwa model $B P N N \# 1$ dan BPNN \#3 mempunyai kontribusi yang paling rendah dalam pendugaan vitamin $\mathrm{C}$ buah jeruk. Hal ini terlihat dari nilai bobot yang paling kecil pada kombinasi $N N E(w=$ 0,21 ). Model BPNN \#4 mempunyai kontribusi yang lebih besar dibandingkan model BPNN \#1 dan BPNN \#3 dalam NNE tersebut untuk memprediksi TPT buah jeruk, sedangkan model BPNN \#2 berkontribusi paling besar yang ditunjukkan dengan nilai bobot yang paling tinggi $(w=0,32)$.

\section{SIMPULAN}

Total padatan terlarut dan vitamin $\mathrm{C}$ buah jeruk siam dapat diestimasi secara nondestruktif menggunakan portable near infrared spectrometer berbasis sensor AS7263 dan neural networks ensemble dengan genetic algorithm untuk optimasi. Hasil estimasi TPT dengan metode wa-NNE sangat akurat dengan MAPE rata-rata $8,04 \%$, sedangkan estimasi vitamin $\mathrm{C}$ tergolong akurat dengan $M A P E$ rata-rata $10,01 \%$. Hasil analisis menggunakan wa-NNE lebih baik dibandingkan sa-NNE maupun BPNN tunggal dengan dua lapisan tersembunyi. Penelitian ini masih perlu dilanjutkan untuk mengetahui performasi alat yang dikembangkan untuk memprediksi mutu internal jeruk jenis lain yang berbeda karakteristik fisikokimianya, seperti ketebalan kulit jeruk, kekerasan buah, tingkat keasaman, kandungan gula, dan kadar air.

\section{UCAPAN TERIMA KASIH}

Ucapan terima kasih disampaikan kepada Lembaga Penelitian dan Pengabdian Masyarakat (LPPM) Universitas Jenderal Soedirman yang telah mendanai penelitian ini melalui skema Riset Institusi Unsoed (RIU) 2020.

\section{DAFTAR PUSTAKA}

Alhamdan, A, -M., Atia, -A., 2018. Nondestructive method to predict Barhi dates quality at different stages of maturity utilising near-infrared (NIR) spectroscopy. International Journal of Food Properties. 20, S2950-S2959. https://doi.org/10.1080/10942912.2017.1387 794

Ams. 2021. AS7263 6-Ch NIR spectral sensing engine. Dilihat 1 Juni 2021. $<$ https://ams.com/as7263>

AOAC. 2005. Official Methods of Analysis of AOAC INTERNATIONAL. Gaithersburg, MD, USA: AOAC International

Chen, R, J, -C., Bloomfield, -P., Cubbage, F, -W., 2008. Comparing forecasting models in tourism. Journal of Hospitality and Tourism Research. 32(1), 3-21. https://doi.org/10.1177/1096348007309566

Departemen Kesehatan Republik Indonesia. 1995. Materia Medika Indonesia, Edisi Ke-6. Departemen Kesehatan Republik Indonesia, Jakarta 
Jurnal Teknologi Pertanian Vol. 22 No. 2 [Agustus 2021] 81-88

Portable Near Infrared Spectrometer dengan Sensor AS7263 untuk Pendugaan Sifat Kimia Jeruk Siam

[Sulistyo dkk]

Dimililer, -K., Kiani, -E., 2017. Application of back propagation neural networks on maize plant detection. Procedia Computer Science. 120, 376-381. https://doi.org/10.1016/j.procs.2017.11.253

Ghasemi, -K., Ghasemi, -Y., Ebrahimzadeh, M, A., 2009. Antioxidant activity, phenol and flavonoid contents of 13 citrus species peels and tissues. Pakistan Journal of Pharmaceutical Sciences. 22(3), 277-281. https://applications.emro.who.int/imemrf/ pak_j_pharm_sci/pak_j_pharm_sci_2009_22_ 3_277_281.pdf

Herulambang, -W., 2016. Modeling the effect of fertilization on growth pattern of Brassica rapa using backpropagation neural network. Journal of Electrical Engineering and Computer Sciences. 1(1), 19-24. https://jeecs.ubhara.ac.id/index.php/Jeec sV1N1/article/view/17

Khodabakhshian, -R., Emadi, -B., Khojastehpour, -M., Golzarian, M, -R., Sazgarnia, -A., 2017. Nondestructive evaluation of maturity and quality parameters of pomegranate fruit by visible/near infrared spectroscopy. International Journal of Food Properties. 20(1), 41-52. https://doi.org/10.1080/10942912.2015.1126725

Lesnussa, Y, -A., Mustamu, C, -G., Kondo Lembang, F., Talakua, M, -W., 2018. Application of backpropagation neural networks in predicting rainfall data in Ambon city. International Journal of Artificial Intelligence Research. 2(2). https://doi.org/10.29099/ijair.v2i2.59

Liang, S, -Y., Han, -D., Han, C, -Z., 2014. A novel diversity measure based on geometric relationship and its application to design of multiple classifier systems. Acta Automatica Sinica. 40(3), 449-458. http://dx.doi.org/10.3724/SP.J.1004.2014.00449

Mi, -A., Wang, -L., Qi, -J., 2016. A multiple classifier fusion algorithm using weighted decision templates. Scientific Programming. 2016, 1-10. https://doi.org/10.1155/2016/3943859

Olabinjo, O,-O., Ogunlowo, A,-S., Ajayi, O,-O., Olalusi, A, -P., 2017. Analysis of physical and chemical composition of sweet orange (Citrus sinensis) peels. International Journal of Environment, Agriculture and Biotechnology (IJEAB). 2(4), 2201-2206. https://dx.doi.org/10.22161/ijeab/2.4.80

Putro, -B., Furqon, M, -T., Wijoyo, S, -H., 2018. Prediksi jumlah kebutuhan pemakaian air menggunakan metode exponential smoothing (studi kasus: PDAM Kota Malang). Jurnal Pengembangan Teknologi Informasi dan Ilmu Komputer. 2(11), 4679-4686. https://j-ptiik.ub.ac.id/index.php/j-

ptiik/article/view/3047

Qomariah,-R., Hasbianto,-A., Lesmayati, -S. Hasan, -H., 2013. Kajian pra panen jeruk siam (Citrus suhuiensis Tan) untuk ekspor. Seminar Nasional Inovasi Teknologi Pertanian. 417-430. http://kalsel.litbang.pertanian.go.id/ind/imag es/pdf/prosiding/41\%20retna.pdf

Rothe, -S., Kudszus, -B., Söffker, -D., 2019. Does classifier fusion improve the overall performance? Numerical analysis of data and fusion method characteristics influencing classifier fusion performance. Entropy. 21(9), 120. https://doi.org/10.3390/e21090866

Ruta,-D., Gabrys, -B., 2000. An overview of classifier fusion methods. Computing and Information Systems. $\quad 7(1), \quad 1-10$. http://decweb.bournemouth.ac.uk/staf f/bgabrys/publications/CIS_2000_Ruta _Gabrys_fusion_methods_overview.pdf Shao, -Y., He, -Y., Bao, -Y., Mao, -J., 2009. Near-infrared spectroscopy for classification of oranges and prediction of the sugar content. International Journal of Food Properties. 12(3), 644-658. https://doi.org/10.1080/1094291080199 2991

Soltanikazemi, -M., Abdanan Mehdizadeh, -S., Heydari,-M., 2017. Non-destructive evaluation of the internal fruit quality of black mulberry (Morus nigra L.) using visible-infrared spectroscopy and genetic algorithm. International Journal of Food Properties. 20111), 2437-2447. https://doi.org/10.1080/10942912.2016.1238930

Sulistyo, S, -B., Wu, -D., Woo, W, -L., Dlay, S, -S., Gao, -B., 2018. Computational deep intelligence vision sensing for nutrient content estimation in agricultural automation. IEEE Transactions on Automation Science and Engineering. 15(3), 1243-1257. https://doi.org/10.1109/TASE.2017.2770170

Rao, V, -N., Manasa, -S., 2019. 2019. Artificial neural networks for soil quality and crop yield prediction using machine learning. International Journal on Future Revolution in Computer Science \& Communication Engineering. 5(1), 57-60. http://www.ijfrcsce.org/index.php/ijfrcsce/ar ticle/view/1835

Zhou, Z, -H., Wu, -J., Tang, -W., 2002. Ensembling neural networks: Many could be better than all. Artificial Intelligence. 137(1-2), 239-263. https://doi.org/10.1016/S0004-3702(02)00190$\mathrm{X}$ 